\title{
ANALISIS EFEKTIVITAS TERAPI PADA PASIEN ANEMIA GAGAL GINJAL HEMODIALISIS DI RSUP DR. WAHIDIN SUDIROHUSODO MAKASSAR
}

\author{
Nurul Insani ${ }^{1}$, Marianti A.Manggau ${ }^{1}$, Hasyim Kasim ${ }^{2}$ \\ ${ }^{1}$ Fakultas Farmasi, Universitas Hasanuddin, Makassar \\ ${ }^{2}$ Departemen Ilmu Penyakit Dalam, Fakultas Kedokteran, Universitas Hasanuddin, Makassar
}

Kata Kunci :

Eritropoetin (EPO), Packed Red Cell (PRC), Anemia, Parameter Hematologi

\section{Masuk 18-07-2018 \\ Revisi 26-07-2018 \\ Diterima 30-07-2018}

Korespondensi

Marianti A. Manggau winati04@yahoo.co.id

Fakultas Farmasi, Universitas Hasanuddin Jalan Perintis

Kemerdekaan Km.10,

Makassar 90245,

Indonesia

Telp. +62-411-588-556

Fax. +62-411-585-188

Copyright

(C) 2018 Majalah Farmasi Farmakologi Fakultas

Farmasi · Makassar

Diterbitkan tanggal 31-07-2018

Dapat Diakses Daring Pada:

http://journal.unhas.ac.id /index.php/mff

\section{ABSTRAK}

Penelitian ini bertujuan untuk menganalisis efektivitas terapi anemia penggunaan EPO,PRC pada pasien gagal ginjal hemodialisis berdasarkan outcome terhadap parameter hematologi meliputi kadar RBC,Hgb,Hct,MCV,MCH,MCHC pasien selama rawat inap di RSUP Dr. Wahidin Sudirohusodo Makassar.Desain penelitian yang digunakan adalah penelitian prospektif dengan rancangan deskriptif. Pengambilan sampel dilakukan dengan teknik non-probability sampling dengan cara purposive sampling, yang mencapai jumlah 27 orang sampel. Data yang dianalisis secara deskriptif berupa parameter hematologi. Hasil penelitian menunjukkan terapi EPO efektif meningkatkan kadar RBC,Hgb,Hct dan MCV pada pasien anemia hemodialisis. Terapi PRC efektif meningkatkan kadar $\mathrm{RBC}, \mathrm{Hgb}, \mathrm{Hct}$ pada pasien anemia hemodialisis. Interaksi obat potensial bermakna yang terjadi antara EPO dengan obat lain yaitu antihipertensi golongan angiotensin receptor blocker.

\section{PENDAHULUAN}

Berdasarkan hasil Riskesdas pada tahun 2013, persentase masyarakat di Indonesia yang mengalami GGK sebanyak 0,2\% dengan jumlah penderita paling banyak berumur diatas 15 tahun (1). Sedangkan menurut Persatuan Nefrologi Indonesia (Pernefri) pada tahun 2006, persentase penderita GGK di Indonesia sebanyak 12,5\% (2).

Penderita GGK stage 5 atau yang disebut end stage renal disease (ESRD) terutama yang menjalani hemodialisis (HD) memiliki resiko terjadinya kompleksitas kondisi, salah satunya adalah resiko menderita anemia. Penyebab utama terjadinya anemia pada penderita GGK yaitu menurunnya produksi hormon eritropoetin, yang mana $90 \%$ hormon ini diproduksi di ginjal. Hormon ini berfungsi merangsang produksi sel darah merah (3-5).

Pada saat ini ada beberapa pilihan terapi yang diberikan untuk mengatasi anemia pada penderita GGK, seperti pemberian epoetin (EPO) eksogen yang merupakan lini pertama dalam terapi anemia GGK, pemberian zat besi apabila pasien terdiagnosa menderita defisiensi besi, dan pemberian transfusi darah Packed Red Cell (PRC) (4-7).

Pemberian terapi EPO telah mengubah tatalaksana terapi anemia GGK, dimana EPO mampu meningkatkan kadar hemoglobin $(\mathrm{Hb})$ serta mampu mengurangi frekuensi pemberian transfusi darah pada penderita anemia GGK $(5,8)$.

Epoetin yang merupakan lini terapi pertama, tidak ditanggung oleh asuransi kesehatan pemerintah menjadi faktor utama tidak optimalnya terapi anemia pada penderita GGK. Untuk mengatasi hal ini maka PRC menjadi pilihan terapi yang paling banyak digunakan. Pedoman pemberian terapi PRC sendiri belum ada yang pasti. KDIGO menyarankan pemberian PRC apabila kadar $\mathrm{Hb}$ dibawah 7 g/dl. Selain itu KDIGO juga menyarankan bahwa pemberian terapi PRC tidak hanya berpatokan pada kadar $\mathrm{Hb}$ penderita saja, tetapi juga perlu mempertimbangkan kondisi klinis atau keadaan simptomatik masing-masing penderita (8).

Selain itu, pada saat penderita GGK menjalani proses hemodialisis, penderita beresiko kehilangan darah yang dapat memperburuk kondisi anemia (10-11). Semakin lama pasien sudah menjalani HD, maka akan semakin meningkatkan faktor resiko penyebab kematian, seperti anemia (7,12).

Pada pasien anemia GGK-HD selain mendapatkan terapi anemia, juga mendapatkan terapi penyerta lain. Terapi penyerta yang paling banyak diberikan adalah antihipertensi, seperti golongan Angiotensin reseptor blocker (ARB) dan golongan diuretik. Berdasarkan penelitian yang telah dilakukan sebelumnya oleh Mohanram, et al antihipertensi golongan ARB ini dapat menyebabkan terjadinya penurunan kadar $\mathrm{Hb}$, yang artinya dapat mempengaruhi terapi anemia dan memperburuk kondisi anemia pada pasien (13).

Pendekatan optimal untuk pengobatan anemia pada pasien dengan penyakit ginjal kronis (GGK) adalah masalah yang masih diperdebatkan. Pentingnya penatalaksanaan anemia yang tepat pada pasien GGK-HD dan permasalahan terkait terapi yang belum optimal, penggunaan obat lain yang dapat mempengaruhi kerja dari terapi utama anemia, serta belum dilakukannya penelitian tentang efek terapi EPO dan PRC pada pasien anemia GGK-HD di Rumah Sakit Wahidin Sudirohusodo Makassar, mendorong untuk dilakukannya penelitian ini. Tujuan penelitian ini 
adalah untuk mengetahui efek terapi EPO dan PRC pada pasien anemia GGK-HD terhadap peningkatan kadar Red Blood Cell (RBC), Hemoglobin (Hb), Hematokrit (Hct), Mean Corpuscular Volume (MCV), Mean Corpuscular Hemoglobin (MCH), Mean Corpuscular Hemoglobin Concentration (MCHC).

\section{METODE PENELITIAN}

\section{Rancangan Penelitian}

Penelitian ini merupakan penelitian deskriptif dengan menggunakan desain prospektif pada pasien anemia CKD-HD yang diberikan terapi eritropoetin (EPO) dan Packed Red Cell (PRC).

\section{Lokasi dan Waktu Penelitian}

Penelitian dilaksanakan periode Februari-Mei 2018 di Rumah Sakit DR. Wahidin Sudirohusodo.

\section{Bahan Penelitian}

Bahan yang digunakan adalah data rekam medik pasien lengkap (data laboratorium RBC, Hgb, Hct, MCV, MCH, MCHC).

\section{Prosedur Kerja}

Pasien dengan anemia CKD yang menjalani HD dengan terapi EPO dan PRC di Rumah Sakit DR. Wahidin Sudirohusodo Makassar dengan data laboratorium kadar $\mathrm{Hb}<11 \mathrm{~g} / \mathrm{dL}$, pasien berusia $\geq 18$ tahun dan pasien melakukan HD selama periode penelitian, data rekam medik pasien lengkap (data laboratorium RBC, Hgb, Hct, MCV, MCH, MCHC). Efektivitas terapi dianalisa dengan melihat perubahan kadar RBC, Hgb, Hct, MCV, MCH, MCHC pasien selama periode penelitian.

\section{Analisis dan Penyajian Data}

Analisis data dalam penelitian ini dilakukan dengan cara analisis deskriptif dari data hasil penelitian mengenai karakteristik subyek disajikan dalam bentuk narasi dan tabel tabel. Data yang diperoleh dilakukan analisis dengan pengolahan data untuk mengetahui perubahan parameter meliputi kadar RBC, Hgb, Hct, MCV, MCH, MCHC sebelum dan sesudah terapi.

\section{HASIL DAN PEMBAHASAN}

Hasil Riskesdas 2013, populasi umur $\geq 15$ tahun yang terdiagnosis gagal ginjal kronis sebesar $0,2 \%$. Angka ini lebih rendah dibandingkan prevalensi CKD di negara-negara lain. Perhimpunan Nefrologi Indonesia (Pernefri) tahun 2006, yang mendapatkan prevalensi CKD sebesar $12,5 \%$. Hal ini karena di Indonesia pasien yang menderita CKD baru terdiagnosis setelah CKD mencapai tahap lanjut dan akhir (1) Faktor risiko anemia lebih besar pada perempuan dari pada laki-laki. Hal ini dapat disebabkan adanya perbedaan simpanan dan kebutuhan zat besi antara laki-laki dan perempuan. Kadar hemoglobin pada perempuan lebih rendah dari pada kadar hemoglobin laki - laki karena pada perempuan mengalami kehilangan besi lebih banyak dibanding laki-laki akibat menstruasi setiap bulannya (14).

Tabel 1. Karakteristik Jenis Kelamin Pasien

\begin{tabular}{ccc}
\hline Jenis Kelamin & Jumlah & Persen \\
\hline Perempuan & 17 & $63 \%$ \\
Laki-laki & 10 & $37 \%$ \\
\hline
\end{tabular}

Hal lain yang dapat menjadi penyebab perburukan anemia adalah phlebotomy dan lamanya pasien menjalani HD. HD umumnya dilakukan tiga kali seminggu sehingga pasien beresiko kehilangan darah. Per tahunnya pasien yang menjalani HD dapat kehilangan darah sekitar 4-5 L. Zat yang ada diplasma pasien dengan CKD, secara kolektif disebut "toksin uremik, "dapat menghambat produksi eritropoetin (EPO), respon sumsum tulang terhadap eritropoetin (EPO). Toksin uremik ini dapat menyebabkan rentang hidup sel darah merah berkurang, dari rentang hidup normal 120 hari menjadi sekitar 60 hari $(3,5,8)$.

\begin{tabular}{ccc}
\multicolumn{2}{l}{ Tabel 2. Karakteristik Umur Pasien } \\
\hline Umur & Jumlah & Persen \\
\hline $20-35$ tahun & 10 & $37 \%$ \\
$36-45$ tahun & 8 & $29 \%$ \\
$46-55$ tahun & 5 & $18,5 \%$ \\
$56-75$ tahun & 4 & $14,8 \%$ \\
\hline TOTAL & 27 & $100 \%$ \\
\hline
\end{tabular}

Mekanisme kerja dari eritropoetin adalah mencegah terjadinya apoptosis, atau kematian sel prekursor erythroid dan untuk memungkinkan proliferasi dan pematangan berikutnya. Apabila tubuh mengalami kekurangan oksigen atau disebut dengan hipoksia maka ginjal akan meningkatkan produksi dan pelepasan eritropoetin untuk merangsang sel induk berdiferensiasi menjadi proerythroblasts, meningkatkan laju dari mitosis, meningkatkan pelepasan retikulosit dari sumsum, dan menginduksi pembentukan hemoglobin (Hb) $(3,4,6)$.

Pada penelitian ini pasien yang memenuhi kriteria inklusi yang mendapatkan terapi EPO sebanyak 10 orang. Dosis EPO diberikan $2000 \mathrm{U}-3000 \mathrm{U}$ dengan frekuensi pemberian $2 \mathrm{kali}$ seminggu. Semua pasien yang mendapatkan terapi EPO memberikan respon yang baik mentolerir terapi EPO dengan baik. Hasil analisis data menunjukkan terjadinya peningkatan pada masing-masing parameter antara sebelum dan setelah penggunaan terapi EPO, untuk semua variabel yang diuji, meliputi RBC, Hct, Hgb, MCV, MCH, kecuali MCHC. Hasil analisis data menunjukkan peningkatan antara sebelum dan setelah penggunaan terapi Packed Red Cell (PRC), untuk semua variabel yang diuji, meliputi RBC, Hct, Hgb, kecuali kadar MCV, MCH dan MCHC.

\begin{tabular}{|c|c|c|}
\hline \multirow{2}{*}{ Variabel } & \multicolumn{2}{|c|}{ Kelompok EPO } \\
\hline & Sebelum Terapi & Sesudah Terapi \\
\hline RBC & $2,91 \pm 0,41$ & $3,27 \pm 0,52$ \\
\hline $\mathrm{Hgb}$ & $7,97 \pm 0,99$ & $9,45 \pm 1,43$ \\
\hline Hct & $23,40 \pm 2,28$ & $28,48 \pm 5,36$ \\
\hline MCV & $84,06 \pm 5,27$ & $87,30 \pm 5,43$ \\
\hline $\mathrm{MCH}$ & $27,62 \pm 1,55$ & $28,25 \pm 1,27$ \\
\hline $\mathrm{MCHC}$ & $32,51 \pm 1,75$ & $32,50 \pm 1,26$ \\
\hline
\end{tabular}

Tabel 4. Efek Terapi PRC berdasarkan nilai $\triangle \mathrm{RBC}, \triangle \mathrm{Hgb}, \triangle \mathrm{Hct}, \triangle \mathrm{MCV}$, $\triangle \mathrm{MCH}$, dan $\triangle \mathrm{MCHC}$

\begin{tabular}{lcc}
\hline \multirow{2}{*}{ Variabel } & \multicolumn{2}{c}{ Kelompok PRC } \\
\cline { 2 - 3 } & Sebelum Terapi & Sesudah Terapi \\
\hline $\mathrm{RBC}$ & $2,63 \pm 0,39$ & $3,16 \pm 0,37$ \\
$\mathrm{Hgb}$ & $7,21 \pm 1,32$ & $9,15 \pm 1,05$ \\
$\mathrm{Hct}$ & $23,05 \pm 4,51$ & $27,77 \pm 3,35$ \\
$\mathrm{MCV}$ & $85,55 \pm 6,07$ & $85,58 \pm 5,79$ \\
$\mathrm{MCH}$ & $28,29 \pm 2,05$ & $28,75 \pm 1,54$ \\
$\mathrm{MCHC}$ & $32,51 \pm 1,40$ & $32,80 \pm 1,00$ \\
\hline
\end{tabular}

MCHC yang rendah selalu menunjukkan hipokromia; sebuah mikrosit dengan konsentrasi Hgb normal akan memiliki MCH rendah, tetapi MCHC normal. Penurunan MCHC paling sering dikaitkan dengan defisiensi besi $(4,5)$. Kekurangan zat besi 
dapat disebabkan karena kehilangan darah dan absorbsi saluran cerna yang buruk. Selain itu, proses hemodialisis dapat menyebabkan kehilangan 3-5 gr besi per tahun. Normalnya, individu kehilangan besi 1-2 mg per hari, sehingga kehilangan besi pada pasien-pasien dialisis 10-20 kali lebih banyak (15-17). Hipokrom berarti mengandung hemoglobin dalam jumlah yang kurang dari normal. Hipokromia terjadi karena cadangan besi tidak memadai sehingga mengakibatkan penurunan sintesis hemoglobin. Disarankan untuk melakukan pemantauan terhadap status besi pasien (4).

\begin{tabular}{|c|c|c|c|c|}
\hline $\begin{array}{c}\text { Interaksi } \\
\text { Obat }\end{array}$ & $\begin{array}{c}\text { Jumlah } \\
\text { Kasus } \\
\mathrm{N}=27 \\
(\%) \\
\end{array}$ & Efek Interaksi & Kategori & Ref \\
\hline $\begin{array}{c}\text { EPO + } \\
\text { Amlodipine }\end{array}$ & $\begin{array}{c}8 \\
(29)\end{array}$ & $\begin{array}{c}\text { Peningkatan tingkat } \\
\text { hematokrit rata-rata } \\
\text { dan penurunan } \\
\text { kebutuhan dosis } \\
\text { epoetin rata-rata }\end{array}$ & $\begin{array}{c}\text { Moderat; } \\
\text { Monitor } \\
\text { Closely }\end{array}$ & (18) \\
\hline $\begin{array}{l}\text { Asam folat + } \\
\text { furosemid }\end{array}$ & $\begin{array}{c}11 \\
(40)\end{array}$ & $\begin{array}{l}\text { Penggunaan diuretik } \\
\text { jangka panjang } \\
\text { meningkatkan } \\
\text { eliminasi folat }\end{array}$ & $\begin{array}{c}\text { Monitor } \\
\text { Closely }\end{array}$ & (18) \\
\hline$E P O+A R B$ & $\begin{array}{c}6 \\
(22)\end{array}$ & $\begin{array}{c}\text { ARB menurunkan } \\
\text { kadar hemoglobin } \\
\text { (mengurangi } \\
\text { efektivitas } \\
\text { EPO),peningkatan } \\
\text { dosis EPO }\end{array}$ & $\begin{array}{c}\text { Monitor } \\
\text { Closely }\end{array}$ & (18) \\
\hline
\end{tabular}

Dalam penelitian ini pasien mendapatkan terapi antihipertensi, sehingga tidak terjadi peningkatan tekanan darah atau dengan kata lain hipertensi pasien terkontrol. Antihipertensi yang paling banyak digunakan dari golongan CCB, ARB, dan diuretik, yaitu amlodipine, valsartan, telmisartan, dan furosemide. Berdasarkan beberapa penelitian sebelumnya, pemberian EPO dengan antihipertensi tersebut memungkinkan terjadinya interaksi, sehingga diperlukan monitoring yang ketat terhadap pasien.

ARB mengganggu sistem renin-angiotensin pada sumsum tulang, yang menggunakan angiotensin reseptor tipe $1 \mathrm{dan} 2$. Reseptor angiotensin tipe 1 berperan dalam proses masuknya sel induk ke dalam siklus sel pada pasien. Selanjutnya, penelitian in vitro telah menunjukkan bahwa angiotensin dapat meningkatkan eritropoiesis, tetapi tetap membutuhkan eritropoietin. Berdasarkan beberapa penelitian yang telah dilakukan sebelumnya, antihipertensi golongan ARB ini menyebabkan penurunan kadar hemoglobin pada pasien dengan cara menghambat prekursor eritroid. Ini dapat menjadi salah satu penyebab terjadinya atau dapat memperburuk anemia, sehingga diperlukan pertimbangan dan monitoring dalam pemberian. Dalam satu analisis retrospektif terhadap pasien dialisis, 18 dari 24 menerima losartan mengalami penurunan hemoglobin, dan
14 dari mereka menggunakan epoetin. Peningkatan tiga sampai empat kali lipat dalam dosis epoetin diperlukan pada pasien ini untuk mengembalikan kadar hemoglobin $(13,18)$.

Pedoman pemberian terapi PRC sendiri belum ada yang pasti. KDIGO menyarankan pemberian PRC apabila kadar $\mathrm{Hb}$ dibawah $7 \mathrm{~g} /$ dl. Selain itu KDIGO juga menyarankan bahwa pemberian terapi PRC tidak hanya berpatokan pada kadar $\mathrm{Hb}$ penderita saja, tetapi juga perlu mempertimbangkan kondisi klinis atau keadaan simptomatik masing-masing penderita (9).

\section{KESIMPULAN}

Penggunaan EPO dan PRC sebagai bagian dari terapi pasien anemia CKD-HD memperlihatkan outcome parameter hematologi yang relatif baik dan aman. Hal ini ditunjukkan dengan peningkatan kadar dari masing-masing parameter hematologi yang diukur.

\section{DAFTAR PUSTAKA}

1. Riskesdas. Riset Kesehatan Dasar 2013. Jakarta: Kementerian Kesehatan.

2. Perhimpunan Nefrologi Indonesia (PERNEFRI). Konsensus manajemen anemia pada penyakit ginjal kronik, 2011. Jakarta; 2011.hlm. 3-15.

3. Srinivasan, R., Fredy, C., Saravanan, J., Mohanta, P. Assessment of erythropoietin for treatment of anemia in chronic kidney failure- ESRD patients. Biomedicine \& Pharmacotherapy 82 (2016) 44-48.

4. Dipiro, J., Robert L. Talbert, Gary C. Yee, Gary R. Matzke, Barbara G. Wells, dan L. Michael Posey. Pharmacotherapy a Pathophysiologic Approach. Seventh Edition. The McGraw-Hill Companies, USA,2008.

5. Koda - Kimble and young's. Applied Theraupetic the clinical Use of Drugs tenth edition, Lippincott Williams \& Wilkins, awolterskluwer business two commerce square,2009.

6. C. Macdougall, Daniel W. Coyne, David Goldsmith. New options for the anemia of chronic kidney disease.2017.

7. KDIGO.Clinical Practice Guideline for the Evaluation and Management of Chronic Kidney Disease.Kidney Int,2013; 2: 1.

8. C. Macdougall. 2015. Anemia and Chronic Renal Failure, UK

9. KDIGO. Red cell transfusion to treat anemia in CKD. Kidney International Supplements; 2012. hlm. 311-6

10. Suwitra, K., 2009. Penyakit Ginjal Kronik, dalam: Buku Ajar Ilmu Penyakit Dalam. hal. 1035-40.

11. Wish, J. ANEMIA IN CHRONIC KIDNEY DISEASE.2012

12. Almeida, F.A.A., Machado, F.C., Moura, J.A., dan Guimarães, A. C. Global AndCardiovascular Mortality and Risk Factors in Patients Under Hemodialysis Treatment. ArquivosBrasileiros De Cardiologia, 2010; 94: 187-192, 201-206, 190-195.

13. Mohanram A, Zhang Z, Shahinfar S. 2008. The Effect of Losartan on Hemoglobin Concentration and Renal Outcome in Diabetic Nephropathy of Type 2 Diabetes. Kidney. 73(5):630-6.

14. Guyton AC, Hall JE. Buku Ajar Fisiologi Kedokteran. Edisi ke-12. Philadelphia: Elsevier-Saunders, 2014: 389-91, 1029-44.

15. Wilson LM. Penyakit ginjal kronik. In: Hartanto H, Susi N, Wulansari P, Mahanani DA, editors: Patofisiologi konsep klinis proses-proses penyakit. 6nd ed. Jakarta: EGC; 2012.p. 912-45.

16. Singh AK. Anemia of Chronic Kidney Disease. Clin J Am 2008; vol. 3: 3-6.

17. Bakris, George, et al. Prevalence and associations of anemia of CKD: Kidney Early Evaluation Program (KEEP) and National Health and Nutrition Examination Survey (NHANES) 1999-2004. American Journal of Kidney Diseases. 2008;5: S46-S55.

18. Baxter, Karen. 2008. Stockley's Drug Interactions. Eighth Edition. Pharmaceutical Press, UK. 